Zimmerling, J. R., C. M. Francis, C. Roy, and A. M. Calvert. 2017. How well does forestry in Ontario's boreal forest emulate natural disturbances from the perspective of birds? Avian Conservation and Ecology 12(2):10. https://doi.org/10.5751/ACE-01102-120210

Copyright (C) 2017 by the author(s). Published here under license by the Resilience Alliance.

Research Paper

\title{
How well does forestry in Ontario's boreal forest emulate natural disturbances from the perspective of birds?
}

\author{
J. Ryan Zimmerling ${ }^{1}$, Charles M. Francis ${ }^{2}$, Christian Roy ${ }^{1}$ and Anna M. Calvert \\ ${ }^{1}$ Canadian Wildlife Service, Environment and Climate Change Canada, Gatineau, Québec, Canada, ${ }^{2}$ Canadian Wildlife Service, \\ Environment and Climate Change Canada, Ottawa, Ontario, Canada
}

\begin{abstract}
Emulating natural disturbance has become a paradigm for biodiversity retention in forest management. This study evaluates the extent to which harvest management practices have created stands that emulate natural fire disturbance from the perspective of bird communities in Ontario, Canada. We compared the relative abundance of forest landbirds at the stand level in mature forest ( $>80$ years old) with that in early-regenerating ( $0-20$ years) and midregenerating (21-80 years) forests originating from fire or timber harvest across the boreal forest of Ontario using over 7000 point counts. Our results indicate that forest harvest management practices in Ontario have created stands that only partially emulate natural fire disturbances in terms of the bird community composition. Total bird abundance and species richness were significantly lower postharvest than postfire in midregenerating forests, although they did not differ in early-regenerating stands. Species-level comparisons revealed several differences between postharvest and postfire stands, as well as among age classes. Although no species was completely missing from any stand type, $8 \%$ of species in early- and $34 \%$ in midregenerating stands were detected significantly less often in postharvest than postfire forests. Some other species were found significantly more often in postharvest stands, while the majority of species detected $(84 \%$ and $71 \%$ in early- and midregenerating stands, respectively) showed no significant difference between disturbance types. Collectively, these results suggest that widespread replacement of fire with logging as the dominant disturbance type will shift the relative abundance of species within Ontario's boreal forest bird community. Quantifying the population-level implications of these shifts requires extrapolating these stand level effects to the landscape level, while considering the actual or anticipated abundance and distribution of forest age classes across the province under different forest management regimes.
\end{abstract}

\section{La foresterie en forêt boréale ontarienne réussit-elle à reproduire les perturbations naturelles telles que perçues par les oiseaux?}

RÉSUMÉ. La reproduction des perturbations naturelles est devenue un paradigme pour la rétention de la biodiversité en aménagement forestier. La présente étude cherchait à évaluer à quel point les pratiques d'aménagement forestier ont généré des peuplements qui reproduisent les perturbations naturelles provenant de feux pour les communautés aviaires en Ontario, Canada. Nous avons comparé l'abondance relative des oiseaux terrestres forestiers à l'échelle du peuplement dans les forêts mûres ( $>80$ ans) avec celle observée dans de jeunes forêts en régénération (0-20 ans) ou des forêts d'âge moyen en régénération (21-80 ans) issus de feux ou de récolte forestière dans la forêt boréale de l'Ontario, au moyen de plus de 7000 points d'écoute. Nos résultats indiquent que les pratiques d'aménagement forestier en Ontario ont généré des peuplements qui reproduisent seulement partiellement les perturbations naturelles issues de feux en termes de composition de la communauté aviaire. L'abondance relative totale des oiseaux et la richesse spécifique étaient significativement plus faibles à la suite d'une coupe qu'à la suite d'un feu dans les peuplements d'âge moyen, mais elles n'étaient pas différentes dans les jeunes peuplements. Les comparaisons à l'échelle des espèces ont révélé plusieurs différences entre les peuplements après coupe ou après feu, de même que parmi les classes d'âge des forêts. Bien qu'aucune espèce ne fût absente dans les divers types de peuplements, $8 \%$ des espèces dans les jeunes peuplements et $34 \%$ des espèces dans les peuplements d'âge moyen ont été détectées significativement moins souvent dans les forêts récoltées que les forêts après feu. Certaines espèces ont été trouvées significativement plus souvent dans les peuplements récoltés, alors que la plupart des espèces détectées $(84$ et $71 \%$ dans les jeunes peuplements et les peuplements d'âge moyen, respectivement) ne montraient pas de différences significatives entre les types de perturbations. Pris dans leur ensemble, nos résultats indiquent que la pratique répandue de substituer la récolte forestière au feu, comme type dominant de perturbations, entraînera des changements d'abondance relative des espèces dans les communautés aviaires de la forêt boréale de l'Ontario. Pour quantifier les effets de ces changements à l'échelle des populations, il faut extrapoler les effets observés à l'échelle du peuplement à celle du paysage, tout en considérant la quantité et la répartition actuelles ou anticipées des classes d'âge des forêts dans la province sous différents régimes d'aménagement forestier.

Key Words: boreal; fire; forest management; harvest; natural disturbance emulation; Ontario; point count

Address of Correspondent: J. Ryan Zimmerling, Canadian Wildlife Service, Environment and Climate Change Canada, Gatineau, Québec, Canada, Ryan.Zimmerling@canada.ca 


\section{INTRODUCTION}

Retention of biodiversity in human dominated landscapes is important for long-term conservation of species and ecosystems. Although the extent of human impacts on natural landscapes continue to increase, only a limited portion is considered protected (15.4\% globally as of 2014; Juffe-Bignoli et al. 2014), placing particular importance on conservation in human-managed areas. Conservation theory supports the importance of biodiversity to ecosystem function, stability, and productivity (e.g., Tilman et al. 1996, Cardinale et al. 2012). Ensuring the retention of a full complement of natural species is believed to be integral to sustainable communities (Mayfield et al. 2010), particularly in forest habitats (Paillet et al. 2010, Zhang et al. 2012), as emphasized by the Secretariat of the Convention on Biological Diversity (2014) and the North American Bird Conservation Initiative (2016).

Emulation of natural disturbance for biodiversity retention has become a key component of ecosystem-based forest management globally (e.g., Bunnell 1995, Perera and Buse 2004, Klenk et al. 2008, Sibley et al. 2012), including in the boreal forests across Canada (Senate Subcommittee on Boreal Forests 1999). This approach assumes that wildlife have adapted over time to forest disturbance resulting from wildfires and, to a lesser degree, insect outbreaks (Hunter 1993, Attiwill 1994, Haila et al. 1994, Niemelä 1999). Consequently, harvesting aimed at emulating the spatial and temporal changes resulting from these natural changes should minimize the loss of biodiversity (Bunnell 1995, Long 2009), at least at a coarse community scale that retains key habitat features required by most species (Cyr et al. 2009, Mayfield et al. 2010). Recent broad-scale assessments suggest that emulation of natural disturbance regimes in northern forests may be generally succeeding in maintaining many ecosystem functions and biodiversity (e.g., Long 2009, Börger and Nudds 2014), though some important knowledge gaps remain (Kuuluvainen and Grenfell 2012, Brandt et al. 2013).

Despite growing support for natural disturbance emulation in biodiversity conservation, empirical tests of this approach have not kept pace with theoretical predictions (Kuuluvainen and Grenfell 2012). Concern has also been raised that incomplete information on forest ecology and historical fire regimes might limit the effectiveness of this paradigm to achieve ecological sustainability (Tiedemann et al. 2000, Macdonald et al. 2004). Identified gaps include the need for improved emulation of natural fire-disturbance intervals (Cyr et al. 2009), incomplete long-term spatial and temporal data on anthropogenic forest change (Venier et al. 2014), and the absence of studies into the processes leading to observed differences in harvested vs. firedisturbed forests (Wyshynski and Nudds 2009; though see Whitaker et al. 2008 for a measure of disturbance-specific demographic parameters, and Bélisle et al. 2007 for a test of evolutionary mechanisms). Predictions that timber harvesting may reduce biodiversity (e.g., Welsh and Venier 1996, Niemi et al. 1998, Askins 2000, Drever et al. 2006, Van Wilgenburg and Hobson 2008) are in contrast with recent evidence for the relative success of harvest management approaches in maintaining biodiversity (e.g., Lemelin et al. 2007, Wychynski and Nudds 2009, Börger and Nudds 2014). This disparity supports the need for continued empirical evaluation of how well harvesting mirrors natural forest processes.
Quantifying both community- and species-level differences in boreal birds between postharvest and postfire forests can be valuable for assessing the effectiveness of natural disturbance emulation (e.g., Rempel 2007, Van Wilgenburg and Hobson 2008). Several studies suggest that some bird species found in naturally disturbed forest stands are significantly less abundant in postharvest stands of similar types and ages, especially in the earliest successional stages but also several decades after harvest (e.g., Schulte and Niemi 1998, Hannon 1999, Imbeau et al. 1999, Simon et al. 2002). However, others find little difference for most species (e.g., Lemelin et al. 2007, Börger and Nudds 2014, Rempel et al. 2016). Lewis et al. (2016) found that waterfowl were relatively unaffected even by natural disturbance in the boreal forest. At the community scale, Drapeau et al. (2000) found that the mean number of mature forest bird species was significantly lower in human-altered landscapes of northern Québec than in naturally disturbed landscapes, largely because of a conversion from mixedwood to deciduous cover. A broad review across North American forests suggests that such a conversion of mature forests could impact some regional bird populations and potentially jeopardize the ecological integrity of these habitats if harvest management practises are not further modified (Drever et al. 2006; see also Hobson and Bayne 2000, Venier et al. 2014).

Comprehensive data spanning a range of forest ages and postdisturbance time frames are important for assessing natural disturbance emulation. Because forest habitats are constantly changing with growth and decay, and as their inhabitants respond to habitat alteration, differences in bird communities between postfire and postharvest habitats may be dynamic (Schieck and Song 2006). For example, Hobson and Schieck (1999) showed that higher snag densities in recently burned vs. harvested mixedwood forests of Alberta were correlated with initially greater abundance of cavity-nesting species, but that snag decay led to some convergence of bird communities after 28 years postdisturbance. By 60 years postharvest, Schieck and Hobson (2000) suggested these differences were virtually eliminated. Song (2002) also found that, as the forest canopy closed, both the bird communities and vegetation structure converged at about 50-60 years postdisturbance. Such findings have led to the general hypothesis that many birds of the boreal forest, where extreme periodic stand-replacing natural disturbances, e.g., fire and insect outbreak, have occurred frequently in the past, may be particularly resilient to disturbances caused by harvest management (Welsh 1987, Schmiegelow et al. 1997, Lemelin et al. 2007, Whitaker et al. 2008, Börger and Nudds 2014; but see discussions in Drever et al. 2006, Schmiegelow and Villard 2009).

Given the critical importance of the boreal forest to landbirds in Canada (Blancher 2003, Blancher and Wells 2005), and the large portion of the boreal forest subject to harvest management practices, the degree of resilience of boreal forest birds to industrial timber harvesting is of particular interest (Schmiegelow and Villard 2009). If birds do differ between naturally and anthropogenically disturbed boreal habitats, identifying the species most affected and the time frame of these effects might reveal mitigation strategies to reduce overall impacts on avian communities (Rempel et al. 2007, 2016). The primary objective of our study was therefore to evaluate the extent to which harvest management practices have emulated natural fire disturbances from the perspective of bird communities and individual bird 
species across a large region of Ontario boreal forest. Using a large data set covering a wide area of northern Ontario, we contrasted postfire vs. postharvest forest bird communities of two age classes ( $<20$ yrs vs. $20-80$ yrs postdisturbance), and also compared these bird communities with those of mature natural forests $>80$ years postfire.

\section{METHODS}

\section{Study area}

This study was conducted throughout the Crown forests of Ontario where commercial timber harvesting occurs, a region that extends from the border of Manitoba to Québec, and covers an area of $240,000 \mathrm{~km}^{2}$. The study area covered two bird conservation regions (BCRs; Fig. 1), which are characterized by their bird communities, habitats, and land uses. The Boreal Softwood Shield (BCR 8) primarily comprises dense boreal forest, which in comparison to the forests of southern Ontario has a limited diversity of tree species. Black spruce (Picea mariana), jack pine (Pinus banksiana), tamarack (Larix laricina), balsam fir (Abies balsamea), trembling aspen (Populus tremuloides), balsam poplar (Populus balsamifera), and white birch (Betula papyrifera) are the dominant species (Thompson 2000), and in various associations cover more than $60 \%$ of the landscape. The Boreal Hardwood Transition Forest (BCR 12) is characterized by a mosaic of deciduous, mixed, and coniferous stands covering more than $65 \%$ of the landscape (OMNR 2001). Species such as sugar maple (Acer saccharum), American beech (Fagus grandifolia), and red oak (Quercus rubra) are common in the southeast of the region, and boreal species such as black spruce, white birch, and jack pine more common in the north.

Fig. 1. Locations of the $32910 \times 10 \mathrm{~km}$ breeding bird atlas squares where sampling took place in the Boreal Softwood Shield and Boreal Hardwood Transition Bird Conservation Regions of Ontario.

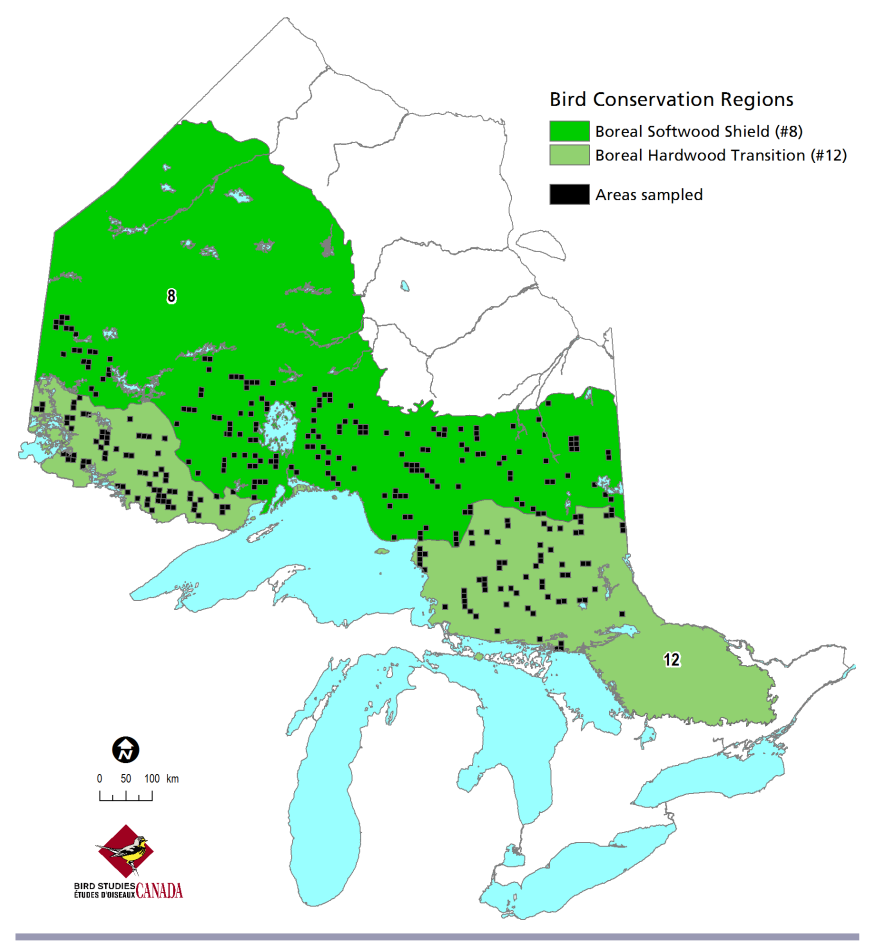

\section{Field methods}

Between 27 May and 19 July 2002 to 2004, bird communities were sampled using point counts in postfire and postharvest forests of various forest ages. The majority of point counts (66\%) were conducted in late May or June and sampling dates were evenly distributed across disturbance histories. Sampling methods were adapted from those used for the second Ontario Breeding Bird Atlas (Cadman et al. 2007). Throughout the study area, $10 \times 10$ $\mathrm{km}$ squares were initially selected using stratified random sampling procedures to ensure that, whenever possible, both postfire and postharvest disturbances were adequately represented for each BCR. For both BCRs, postharvest disturbances were limited to clear-cuts; other types of harvesting, e.g., selective/partial harvesting, were excluded from sampling to avoid confounding our analyses. To maximize the number of areas that could be sampled per unit effort, the majority $(85 \%)$ of sample sites were selected in areas with road access. However, special efforts were also made to sample unroaded areas, through air and canoe access, to ensure adequate coverage of areas that had not been subject to forest management.

Within each $10 \times 10 \mathrm{~km}$ square, four separate U-shaped transects of six point count locations each were established. Transect starting locations were randomly chosen with the constraint that they must be at least $1.5 \mathrm{~km}$ apart on roads or on waterways, i.e., rivers or lakeshores. Roadside starting locations used the first four randomly selected points that met these criteria that had been generated for use during the Ontario Breeding Bird Atlas (Cadman et al. 2007). The maps provided to observers contained no disturbance or forest type information so that observers were unaware of disturbance history (postfire vs. postharvest) when conducting surveys unless there were obvious signs such as cut stumps. In roadless areas ( $>1000 \mathrm{~m}$ from the nearest road), a similar protocol was used with the exception that starting points were defined by natural waterways, i.e., lakes or rivers, or geophysical features. Adjacent points in each U-shaped transect were separated by a minimum distance of $250 \mathrm{~m}$. In most cases, two points (the first and last sampled) occurred on a roadside, two at $250 \mathrm{~m}$ from the road, and two at $500 \mathrm{~m}$ from the road. These six points composed a sampling cluster.

Observers were asked to select point count locations within a single habitat type, i.e., a single forest stand, in such a way that most of the habitat $(>70 \%$ ) within a $100 \mathrm{~m}$ radius of the point was in the same forest stand. The precise coordinates of each point count location were recorded using a GPS. Each point was sampled only once during the breeding season, to maximize the number of different locations that could be sampled with the crews available. Thus, we traded off less precise information on individual locations with greater power to detect large-scale patterns.

The basic sampling protocol involved conducting point counts that were 5-min long within the first 5 hours after dawn. Typically, two clusters could be sampled by a single observer within the morning survey window. With highly skilled observers, preliminary trials suggested that 10 -min point counts added $<1$ additional species compared to 5 -min point counts (Zimmerling, unpublished data), and would have decreased the number of stations that could be sampled. In addition, this protocol allowed surveys to be integrated into the Ontario Breeding Bird Atlas (Cadman et al. 2007). Surveyors recorded all species seen or heard, 
with individuals detected within $100 \mathrm{~m}$ recorded separately from those beyond $100 \mathrm{~m}$. To ensure that birds were within the treatment areas, only birds estimated to be within $100 \mathrm{~m}$ of the point count location were included in our analyses. Only adults were recorded. Point counts were conducted in favorable weather conditions and were not conducted during precipitation or in wind $>20 \mathrm{~km} / \mathrm{h}$, both of which reduce the detectability of singing birds. No playbacks or methods of increasing bird detections, e.g., "pishing" (see Zimmerling and Ankney 2000, Zimmerling 2005) were used during point counts. There was no relationship between the time of a survey within the morning.

To minimize the influence of variation among observers in detection probability during point counts (Farnsworth et al. 2005), all observers hired for field work were selected based on their ability to accurately and consistently identify species on recordings of actual point counts made the previous year in similar habitat. Moreover, to the extent possible, each observer conducted point counts in both BCR 8 and BCR 12 and within all habitat types, to reduce the risk that any residual variation among observers would be correlated with treatments.

\section{Disturbance classification}

Maps and digital data provided by forestry companies were used to determine disturbance type (harvest vs. fire) and forest age for each point count location, based on the coordinates reported by the field observers. However, in some regions, these maps and digital data were either incomplete or unavailable. Several forestry companies were unable to provide specific age class data prior to digitization in the early 1980s. In such instances, a combination of vegetation data, hard-copy maps, discussions with forest practitioners, forest resource inventory data, and remotely sensed landcover data were used to determine treatment history.

Disturbance data were categorized into two types: disturbances originating from fire (hereafter postfire) and disturbances originating from timber harvesting (hereafter postharvest). Point counts in other disturbance types, e.g., windthrow and insect outbreaks, were excluded from analysis because sample sizes were too small and the resulting postdisturbance landscapes are structurally and chemically different than those produced by fire (e.g., Campbell 2001).

For all analyses, forests were categorized into three age classes based on time since disturbance: early-regenerating $(<20$ years since disturbance; i.e., disturbed between 1983 and 2004), midregenerating (20-80 years; i.e., disturbed 1921-1982), and mature ( $>80$ years; last disturbed prior to 1920$)$. We were unable to use more precise age categories because this information was lacking for most previous logged sites. Relatively precise information on year of most recent harvest ( \pm 2 years) was only available for about $5 \%$ of previously harvested sites, and decade of most recent harvest for only $11 \%$ more. Thus, for most logged sites we were only able to determine whether the most recent disturbance was more than or less than 20 years. Although better information was available on fires, we needed to use the same categories for comparison. The oldest age class ( $>80$ years) was only relevant for postfire disturbance, because large-scale modern commercial forestry operations did not begin in most of the study area until after the 1920s. The resulting five age/disturbance habitat types (early-postfire, midpostfire, mature-postfire, early-postharvest, midpostharvest) were assessed throughout our analyses.
We focused our analyses on landbird species (see Appendix 1 for full list of species analyzed) because point counts are well suited to surveying these species in forested habitats, and other taxa that rely on the boreal forest, e.g., waterfowl, shorebirds, and marshbirds, are generally rarely detected and hence usually had inadequate sample sizes. Landbird taxa with sufficient sample sizes for analysis included hawks, grouse, woodpeckers, and passerines.

\section{Data analysis}

Two levels of analysis, at community- and species-levels, were completed. The community-level analysis examined the total bird abundance and species richness detected at each point count location. Preliminary analysis indicated that both community level metrics were overdispersed so we used a negative binomial model to analyze the data (Eq. 1).

$$
Y_{i} \sim \mathrm{NB}\left(\mu_{i}, \phi\right)
$$

where $Y$ is the number of birds or species observed at plot $i, \mu$ is the mean, and $\phi$ is the parameter that controls overdispersion relative to the square of the mean. This parametrization of the Negative binomial is commonly referred as the NB2 (Lindén and Mäntyniemi 2011).

$$
\begin{gathered}
\log \left(\mu_{i}\right)=\mathrm{BCR}_{i}+\mathrm{Age}_{i}+\text { Disturbance }_{i} \\
+ \text { Age } \times \text { Disturbance }_{i}
\end{gathered}
$$

We used BCR, disturbance type, age class, and an interaction between disturbance type and age class as explanatory variables on the log scale for the mean (Eq. 2). We initially included a random effect for cluster, but this did not improve model fit, so it was dropped.

The species-level analysis examined the relative abundance of individual species within postharvest and postfire point count locations. To compare species abundance among age classes, we only considered data from postfire disturbances because none of the mature forest stands had previously been logged. Comparisons among disturbance types were done separately for each of the younger age classes. Species were included in the analysis only if they were detected at a minimum of 72 point count locations, i.e., $1 \%$ of all point counts. Individual species models were fitted via a negative binomial regression with disturbance type, age class, and an interaction between disturbance type and age class as explanatory variables and BCR as a covariate. The model also included a random effect for cluster to account for the possibility of autocorrelation among points in the same cluster, e.g., clumped species distributions.

All regressions were fitted in a Bayesian framework that was implemented in Stan (Carpenter et al. 2017) from R using the rstan package (Stan Development Team 2016). We used noninformative priors for all parameters. Model convergence was visually evaluated and verified using the Gelman-Rubin statistic ( $\mathrm{R}^{2}$; Gelman et al. 2014). One of the major advantages of using a Bayesian approach fitted using Markov chain Monte Carlo (MCMC) is that derived parameters and their credible intervals can be estimated from the posterior distribution (Kéry 2010, Kruschke 2014). In our case, the contrasts between the disturbance type, age class, and interactions were derived directly from the model output. Contrasts between two levels of an 
explanatory variable, e.g., postfire vs. postharvest, represent the natural $\log$ of the ratio between the expected values of those two levels and are presented with $95 \%$ Bayesian credible intervals (BCI). Differences were considered significant if the $95 \% \mathrm{BCI}$ did not overlap zero. In some cases, these were back-transformed into percentage differences.

\section{RESULTS}

A total of 7114 point counts, clustered in 1354 clusters in 329 atlas squares across the boreal forest of Ontario (Fig. 1), were included in the analyses. Of those point counts, $27 \%(\mathrm{~N}=1902)$ were conducted in early-regenerating stands, $32 \%(\mathrm{~N}=2287)$ in midregenerating stands, and $41 \%(\mathrm{~N}=2925)$ in mature stands; $66 \%(\mathrm{~N}=4716)$ of the stations were in postfire stands while $34 \%$ $(\mathrm{N}=2398)$ of the stations were in postharvest stands. A total of 68,574 individuals birds were recorded during the point counts, representing 106 landbird species. However only 62 species were recorded on at least at $1 \%$ of all point counts and were therefore used for analysis $(\mathrm{N}=65,487$ individuals; see Appendix 1 for included species and their scientific names).

\section{Community level results}

We did not find consistent differences between BCRs in species richness (contrast between estimated means: $=0.020 ; 95 \%$ Bayesian credible interval $[-0.003-0.044])$ or total abundance (= 0.017 [ $-0.009-0.042]$ ). In postfire forests, numbers of individuals per point count and of species per point count were highest in early-regenerating stands, slightly lower in mature stands and lowest in midregenerating stands (Fig. 2). Contrasts show that estimated species richness was not significantly $(1.3 \%[-3.4-$ $5.7 \%]$ ) higher in early-regenerating than mature stands, but total abundance was $9.1 \%(3.9-14.4 \%)$ higher in early-regenerating stands. Species richness was $9.7 \%(6.7-12.6 \%)$ lower and total abundance was $9.5 \%(6.2-12.7 \%)$ lower in midregenerating stands when compared to mature stands.

In midregenerating stands, both species richness $(-5.7 \%[-9.4-$ $-1.8 \%])$ and total abundance $(-7.1 \%[-11.3--2.8 \%])$ were significantly lower in postharvest stands (Fig. 2). However, postharvest early stands did not differ significantly from postfire early-regenerating stands for either species richness $(2.1 \%[-2.7$ $7.0 \%])$ or total abundance $(-1.7 \%[-6.7-3.6 \%])$.

\section{Species level results}

As expected, many species differed in abundance between mature and younger forests (Fig. 3, Table 1; see Appendix 2 for estimated average abundance of all species in each stand type). Overall, 20 species $(31 \%)$ were significantly less abundant in earlyregenerating stands than in mature stands while 16 species $(26 \%)$ were significantly more abundant in early-regenerating stands than in mature stands (Fig. 3, third column; Table 1). Similarly, 19 species $(31 \%)$ were significantly less abundant in midregenerating than mature stands, while 5 species $(8 \%)$ were significantly more abundant in midregenerating stands than in mature stands (Fig. 3, fourth column; Table 1). Overall, 28 species $(45 \%)$ were consistently more abundant in mature forest than in either early- or midregenerating forests, of which $11(18 \%)$ were significant in both contrasts: American Redstart (Setophaga ruticilla), Blackburnian Warbler (Setophaga fusca), Brown Creeper (Certhia americana), Black-throated Green Warbler
Fig. 2. Predicted total number of individuals (a) and number of species (b) observed per point count in early-regenerating, midregenerating, and mature forest stands, for postfire (left; black) and postharvest (right; grey) habitats in Bird Conservation Region 8 in Ontario. Dots represent the mean and bars represent the $95 \%$ Bayesian credible intervals.
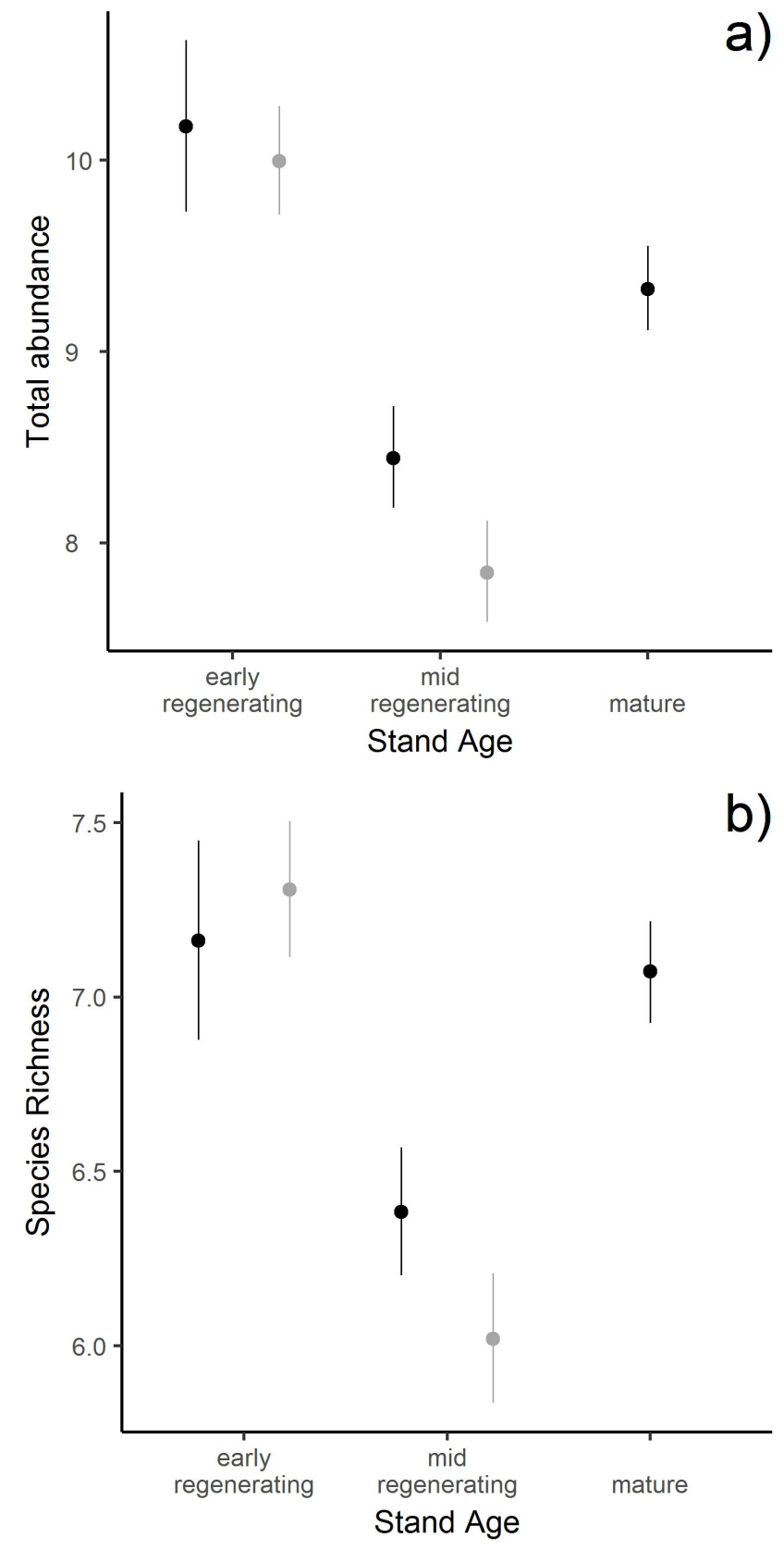

(Setophaga virens), Magnolia Warbler (Setophaga magnolia), Northern Parula (Setophaga americana), Purple Finch (Haemorhous purpureus), Red-breasted Nuthatch (Sitta canadensis), Swainson's Thrush (Catharus ustulatus), Winter Wren (Troglodytes hiemalis), and Yellow-bellied Sapsucker 
Fig. 3. Contrasts between disturbance types (harvest vs. fire) and age classes (early- or midregenerating vs. mature) in estimated abundance of boreal bird species in northern Ontario forest stands. Species are ordered according to the values in the first column. Negative values indicate species that were less abundant in postharvest than postfire stands (first two columns), or less abundant in early- or midregenerating than mature stands (last two columns). The scale is natural $\log$, such that a value of 0.7 corresponds to double (or half) the abundance. Dots represent the mean and bars represent the $95 \%$ Bayesian credible intervals. Black is used when the $95 \%$ credible intervals of the estimates do not overlap zero. See Appendix 1 for vernacular and scientific names of all species listed.
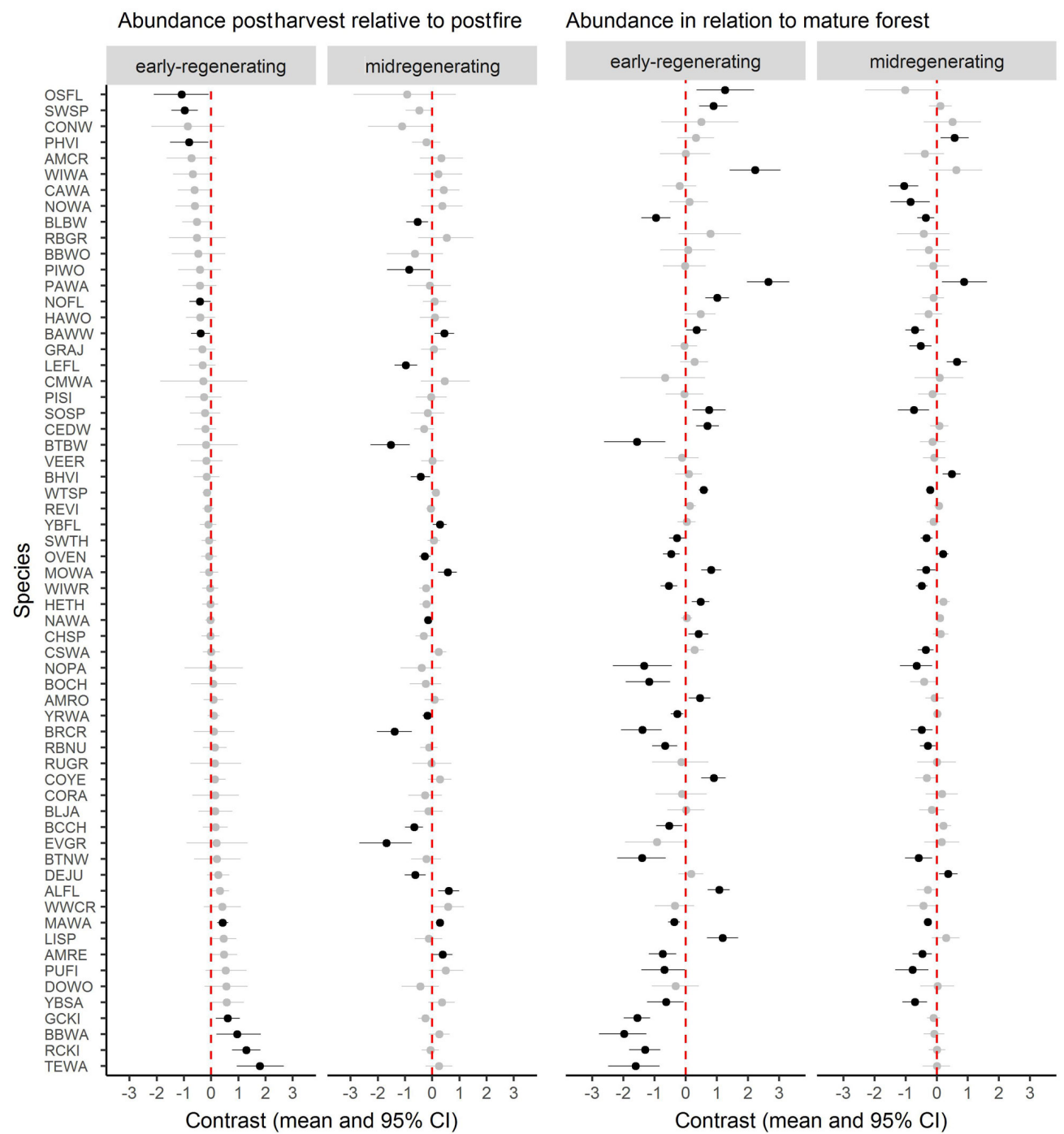

(Sphyrapicus varius). Conversely, 21 species (34\%) were consistently more abundant in the younger age classes, though only 1 was significant in both contrasts: Palm Warbler (Setophaga palmarum). Four species $(6 \%)$ were significantly more abundant in early-regenerating stands in relation to mature forests, but significantly less abundant in midregenerating forests: Black-andwhite Warbler (Mniotilta varia), Mourning Warbler (Geothlypis philadelphia), Song Sparrow (Melospiza melodia), and Whitethroated Sparrow (Zonotrichia albicollis), while one species was significantly less abundant in early-regenerating stands, but more abundant in midregenerating stands, in relation to mature stands: Ovenbird (Seiurus aurocapilla).

Several species were less abundant postharvest than postfire in regenerating forests, while others showed the opposite pattern, and the differences were not always consistent across age classes. In early-regenerating stands, 5 species $(8 \%)$ were significantly less abundant postharvest than postfire, and 5 species $(8 \%)$ were significantly more abundant postharvest than postfire (Fig. 3, first column; Table 2). The differences were more pronounced in midregenerating forest stands, where 12 species (19\%) were 
significantly less abundant postharvest, and 6 species $(10 \%)$ were significantly more abundant postharvest (Fig. 3, fourth column; Table 2). Only one species (Magnolia Warbler) was consistently more abundant in postharvest stands. One species (Black-andwhite Warbler) was less abundant in postharvest habitat in earlyregenerating stands but more abundant in harvested habitat in midregenerating stands (Fig. 3; Appendix 3).

Table 1. Numbers of boreal landbird species in northern Ontario that were more or less abundant in mature forest relative to earlyor midregenerating stands, classified by the direction and significance of the contrast, where significant [sig] or nonsignificant [ns] was based on whether or not the Bayesian credible intervals include zero. For instance, 11 species were significantly less abundant in early-regenerating than mature stands and were also significantly less abundant in midregenerating than mature stands (bottom left cell). See Figure 3 [third and fourth columns] and Appendix 3 (panel a) for individual species contrast values.

\begin{tabular}{lccccc}
\hline \hline & $\begin{array}{c}\text { Early }<< \\
\text { Mature } \\
(\mathrm{sig})\end{array}$ & $\begin{array}{c}\text { Early }< \\
\text { Mature } \\
(\mathrm{ns})\end{array}$ & $\begin{array}{c}\text { Early }> \\
\text { Mature } \\
(\mathrm{ns})\end{array}$ & $\begin{array}{c}\text { Early }>> \\
\text { Mature } \\
(\mathrm{sig})\end{array}$ & Total \\
\hline $\begin{array}{l}\text { Mid }>>\text { Mature } \\
\text { (sig) }\end{array}$ & 1 & 0 & 4 & 1 & 6 \\
$\begin{array}{l}\text { Mid }>\text { Mature } \\
(\mathrm{ns})\end{array}$ & 3 & 5 & 3 & 6 & 17 \\
$\begin{array}{l}\text { Mid }<\text { Mature } \\
(\mathrm{ns})\end{array}$ & 5 & 5 & 5 & 5 & 20 \\
$\begin{array}{l}\text { Mid }<<\text { Mature } \\
\text { (sig) }\end{array}$ & 11 & 2 & 2 & 4 & 19 \\
Total & 20 & 12 & 14 & 16 & 62 \\
\hline
\end{tabular}

A comparison of disturbance-contrasts (i.e., mean estimated abundance ratios between postharvest vs. postfire stands) with the age-contrasts (mean estimated abundance ratios between mature vs. early/midregenerating stands) suggests a link between age- and disturbance-associations of many boreal bird species (Table 3). Nearly two-thirds of species (20/32) that were less abundant in early-regenerating than mature stands were also more abundant postharvest than postfire, with five species significant in both contrasts: Bay-breasted Warbler (Setophaga castanea), Golden-crowned Kinglet (Regulus satrapa), Magnolia Warbler, Ruby-crowned Kinglet (Regulus calendula), Tennessee Warbler (Oreothlypis peregrina), while three-quarter of species (23/30) that were more abundant in early-regenerating than mature stands were less abundant postharvest than postfire, with four species significant for both contrasts: Black-and-white Warbler, Olivesided Flycatcher (Contopus cooperi), Northern Flicker (Colaptes auratus), Swamp Sparrow (Melospiza georgiana; Table 3). Most species $(21 / 23)$ with higher abundance in midregenerating than mature stands also showed lower abundance in postharvest than postfire stands, with four species significant for both contrasts: Least Flycatcher (Empidonax minimus), Dark-eyed Junco (Junco hyemalis), Blue-headed Vireo (Vireo solitarius), Ovenbird, and $62 \%$ of species (24/39) that were less abundant in midregenerating than mature stands showed greater abundance in postharvest than postfire stands, also with four species significant for both contrasts: Mourning Warbler, Black-and-white Warbler, Magnolia Warbler, American Redstart (Table 3). There were no species that were significantly less abundant in early-regenerating than mature forests while also significantly less abundant postharvest than postfire, and also no species that were more abundant in midregenerating than mature forests while also significantly more abundant postharvest than postfire (Table 3 ).

Table 2. Numbers of boreal landbird species that were more or less abundant postharvest than postfire in northern Ontario in early- vs. midregenerating stands, classified by the direction and significance of the contrast, where significant [sig] or nonsignificant [ns] was based on whether or not the Bayesian credible intervals include zero. For instance, no species were significantly less abundant in postharvest than postfire stands of both early- and midregenerating age classes (bottom left cell). See Figure 3 [first two columns] and Appendix 3 (panel b) for individual species contrast values.

\begin{tabular}{|c|c|c|c|c|c|}
\hline & \multicolumn{5}{|c|}{ Early-regenerating } \\
\hline & $\begin{array}{c}\text { Harvest } \\
<<\text { Fire } \\
\text { (sig) }\end{array}$ & $\begin{array}{c}\text { Harvest } \\
<\text { Fire } \\
\text { (ns) }\end{array}$ & $\begin{array}{c}\text { Harvest } \\
>\text { Fire } \\
(\mathrm{ns})\end{array}$ & $\begin{array}{c}\text { Harvest } \\
\text { >> Fire } \\
\text { (sig) }\end{array}$ & Total \\
\hline \multicolumn{6}{|l|}{ Midregenerating } \\
\hline $\begin{array}{l}\text { Harvest }>>\text { Fire } \\
\text { (sig) }\end{array}$ & 1 & 2 & 2 & 1 & 6 \\
\hline $\begin{array}{l}\text { Harvest > Fire } \\
\text { (ns) }\end{array}$ & 1 & 11 & 6 & 2 & 20 \\
\hline $\begin{array}{l}\text { Harvest < Fire } \\
(\mathrm{ns})\end{array}$ & 3 & 10 & 9 & 2 & 24 \\
\hline $\begin{array}{l}\text { Harvest }<<\text { Fire } \\
\text { (sig) }\end{array}$ & 0 & 7 & 5 & 0 & 12 \\
\hline Total & 5 & 30 & 22 & 5 & 62 \\
\hline
\end{tabular}

\section{DISCUSSION}

Our results generally are consistent with the idea that boreal inhabitants may be particularly resilient to harvesting, possibly the result of their historical exposure to regular natural disturbances (e.g., Schmiegelow et al. 1997, Lemelin et al. 2007, Whitaker et al. 2008, Börger and Nudds 2014). The majority of landbird species sampled $(84 \%$ for early- and $71 \%$ for midregenerating stands) showed similar abundance, i.e., nonsignificant difference, between postharvest and postfire forests, which suggests that past harvest management has created some habitats that are generally as suitable for these species as forests originating from fires. No species were found exclusively in postfire or postharvest forests. Similarly, Rempel et al. (2016) found that although several forest condition indicators, e.g., conifer/deciduous ratios or edge density, differed between naturally and anthropogenically disturbed sites, occupancy rates of most (11/14) species were similar between disturbance types.

Nevertheless, our comparisons between postharvest and postfire landscapes indicate that harvesting in Ontario has not completely emulated natural disturbance for some species of boreal birds. At the community scale, our results indicate lower species richness and abundance in postharvest than postfire stands, but only at the intermediate (midregenerating) age class. At the species level, many species showed significantly higher or lower abundance in postharvest relative to postfire forests in either early- (10 species) or midregenerating (18 species) stands. However, few species 
Table 3. Numbers of boreal landbird species in northern Ontario that were more or less abundant in mature than younger stands, versus more or less abundant postfire than postharvest, for early- and midregenerating stands. Values are classified by the direction and significance of the contrast, where significant [sig] or nonsignificant [ns] was based on whether or not the Bayesian credible intervals include zero. For instance, in early-regenerating forests, there were four species that were significantly less abundant postharvest than postfire while also being significantly more abundant in younger than mature stands (top left cell). See Figure 3 and Appendix 3 (panels $\mathrm{c}$ and d) for individual species contrast values.

\begin{tabular}{|c|c|c|c|c|c|c|c|c|c|c|}
\hline & \multicolumn{4}{|c|}{ Early-regenerating } & \multirow[b]{2}{*}{ Total } & \multicolumn{4}{|c|}{ Midregenerating } & \multirow[b]{2}{*}{ Tota } \\
\hline & $\begin{array}{c}\text { Harvest }<< \\
\text { Fire (sig) }\end{array}$ & $\begin{array}{c}\text { Harvest < } \\
\text { Fire (ns) }\end{array}$ & $\begin{array}{c}\text { Harvest }> \\
\text { Fire (ns) }\end{array}$ & $\begin{array}{l}\text { Harvest }>> \\
\text { Fire (sig) }\end{array}$ & & $\begin{array}{c}\text { Harvest }<< \\
\text { Fire (sig) }\end{array}$ & $\begin{array}{c}\text { Harvest }< \\
\text { Fire (ns) } \\
\end{array}$ & $\begin{array}{c}\text { Harvest }> \\
\text { Fire (ns) }\end{array}$ & $\begin{array}{c}\text { Harvest }>> \\
\text { Fire (sig) }\end{array}$ & \\
\hline $\begin{array}{l}\text { Younger }>>\text { Mature } \\
\text { (sig) }\end{array}$ & 4 & 8 & 4 & 0 & 16 & 4 & 2 & 0 & 0 & 6 \\
\hline Younger > Mature (ns) & 1 & 10 & 3 & 0 & 14 & 4 & 11 & 2 & 0 & 17 \\
\hline Younger < Mature (ns) & 0 & 7 & 5 & 0 & 12 & 2 & 6 & 10 & 2 & 20 \\
\hline $\begin{array}{l}\text { Younger }<<\text { Mature } \\
\text { (sig) }\end{array}$ & 0 & 5 & 10 & 5 & 20 & 2 & 5 & 8 & 4 & 19 \\
\hline Total & 5 & 30 & 22 & 5 & 62 & 12 & 24 & 20 & 6 & 62 \\
\hline
\end{tabular}

exhibited consistent differences in both age classes, suggesting that harvest alters species composition, but that its impacts vary with successional age (e.g., Hobson and Schieck 1999, Schieck and Song 2006). Several other studies in boreal forests have reported greater compositional dissimilarities between burned and harvested sites immediately following disturbance than at later successional stages (Hobson and Schieck 1999, Imbeau et al. 1999, Schieck and Hobson 2000, Morissette et al. 2002, Hannon and Drapeau 2005). Although we did not find this, it is also important to note that the midregenerating harvested forests in our study would have been affected by harvest practises that occurred before widespread adoption of efforts to emulate natural disturbance (see Drapeau et al. 2000). For example, there would not have been efforts to retain residual forest cover (i.e., wildlife trees, snags), downed woody debris, and other structure, and silviculture practices may have differed, all of which may have contributed to some of the greater differences in midregenerating stands. Additionally, because precise information on the year of harvest was unavailable for most stands, we cannot preclude the possibility that the average age of midregenerating postharvest and postfire stands differed, further influencing bird community assemblages in midregenerating stands.

Our findings are also consistent with other evidence that vegetation successional patterns affect bird community composition after disturbance (e.g., Schulte and Niemi 1998, Hobson and Schieck 1999, Thompson et al. 1999, McRae et al. 2001, Simon et al. 2002). Community-level estimates were consistent with the idea that species richness in temperate forests is generally greater in younger successional communities, because recently disturbed ecosystems typically have greater nutrient availability and energy exchange than older ecosystems (Gower et al. 1996). At the species scale, many species associated with open habitat showed greater abundance in early-regenerating than older stands, e.g., Alder Flycatcher (Empidonax alnorum), Cedar Waxwing (Bombycilla cedrorum), Common Yellowthroat (Geothlypis trichas), Northern Flicker. Other species peaked in abundance in mature forest, e.g., Brown Creeper, Northern Parula, Red-breasted Nuthatch, Swainson's Thrush, Winter Wren, suggesting they prefer more mature trees, more complex structure or large patches of contiguous forest. Few species showed greatest abundance in midregenerating stands, perhaps because these stands no longer have the high nutrient richness of early stands and do not yet have the quality of mature forests. Finch et al. (1997) argue that such responses of individual species should be a key concern for forest managers because each species' response is unique, and because management strategies are often speciesspecific. Additionally, associations between age-contrasts and disturbance-contrasts suggest that species that are more abundant in early-regenerating than mature stands are less abundant in postharvest than postfire forests and vice versa, although the factors driving this association are unknown. This suggests that changing from predominantly fire disturbance to predominantly harvest disturbance could have greatest impacts on early successional species.

Although we would not anticipate a total loss of any boreal species with harvesting in this region, our results imply a probable shift in relative abundance for a number of species, including mature-forest inhabitants. Our study was not able to compare mature, i.e., $>80$ years, postfire forests with mature postharvest forests, but some species were most abundant in large tracts of forests that are older than rotational age. For example, $18 \%$ of all species analyzed, including Blackburnian Warbler, Brown Creeper, Red-breasted Nuthatch, Swainson's Thrush, and Winter Wren, were significantly more abundant in mature forests than in either early- or midregenerating stands. Other authors (e.g., Titterington et al. 1979, Welsh 1981, Schieck et al. 1995, Cumming and Diamond 2002) have found similar associations with mature forest. We found that all mature-forest species also occurred in early- and midregenerating postdisturbance forests, albeit at lower densities, suggesting that they may find some habitat in managed areas. Blancher et al. (2009) did not find any difference in population trend between birds associated with mature forest and those preferring early successional stages, but this may reflect, in part, the extent of remaining intact forest. Previous studies (e.g., Drapeau et al. 2000, Campbell 2001) have projected that species associated with mature forests will significantly decline over the next 40 years as a result of forest harvesting, due to reductions in the remaining area of mature forest. This supports the idea that maintaining mature forests in a portion of the harvested landscape is necessary for effective emulation of natural disturbances. 
Blancher et al. (2009) did not find any difference in population trend between birds associated with mature forest and those preferring early successional stages, but this may reflect, in part, the fact that only a limited part of the landscape has been harvested.

Understanding the underlying reasons for differences between postharvest and postfire communities could help improve management techniques to more closely emulate natural disturbance (Rempel et al. 2016). For instance, snag density is an important structural feature that differs between postharvest and postfire forests (Zimmerling, unpublished data). In the years immediately following an intensive fire, species that use shrubs and understory vegetation for nesting and foraging will have very little habitat, whereas those that use snags will have abundant habitat (e.g., Imbeau et al. 1999, Hannon and Drapeau 2005). In contrast, many harvesting methods leave behind few snags. Although the present study was not designed to target snagnesters and foragers, several snag-specialist species were indeed more abundant in postfire forests (e.g., Northern Flicker and Olive-sided Flycatcher, though only in early-regenerating stands) than in postharvest forests, a result consistent with other studies despite differences in forest type and geographic location (Hutto 1995, Morissette et al. 2002). However, given that patterns between guilds, e.g., snag-specialist, and disturbance histories were inconsistent, our results may not be readily generalizable. Fire suppression since the 1950s in the southern boreal continues to reduce the amount of younger, burned forests with numerous snags, and thus recent changes in forest management guidelines and practices in Ontario to increase wildlife tree retention, including snags, to an average of 25 trees / ha may be especially important (OMNR 2001, 2010).

Collectively, our results suggest that if harvest becomes an increasingly common disturbance in Ontario's boreal region, there will be important changes in species composition within the forest bird community. Quantifying the population-scale impacts of these shifts requires extrapolation of these stand-level effects to the landscape-level, by accounting for the projected amounts of each habitat type in the landscape (see Drapeau et al. 2000). Effective emulation of natural disturbances must consider landscape-scale habitat change in burned vs. harvested areas in the context of current and future forest age class distribution, and across a range of alternative forest management strategies.

\section{CONCLUSION}

The boreal forest is a critical habitat for North American wildlife (Blancher 2003, Blancher and Wells 2005, Brandt et al. 2013), and population declines in many bird species have been partially attributed to harvest management (e.g., Schmiegelow and Monkkonen 2002). We found that more than half of the boreal landbird species responded similarly to disturbances by fire and harvest, perhaps attesting to both the success of management efforts to emulate natural disturbances, as well as the resilience of many boreal birds (e.g., Schmiegelow et al. 1997, Lemelin et al. 2007). Nonetheless, important differences in abundance between disturbance types in both early- and midregenerating stands suggest that the extent to which harvest emulates natural disturbances depends on forest age, as well as specific habitat features. Thus relative species abundance could vary with future harvesting, even if most species manage to persist.
It is not realistic to expect any degree of harvest management to fully replicate the natural habitat diversity of postfire forests. Forestry research would benefit from quantification of how widely managed forests can diverge from natural habitats without severely compromising biodiversity and sustainability (Delong and Tanner 1996, Perry 1998, Drever et al. 2006, Rempel et al. 2016), with the objective of planning harvest to replicate natural disturbance events as closely as possible. Boreal forest inhabitants require a complex landscape matrix of diverse habitat features, including trees of various ages and structures as affirmed by our results. It is thus the retention or replication of these conditions in harvesting that is required to meet the coarse-filter needs of entire boreal forest bird communities (Bergeron et al. 2002, Vitz and Rodewald 2006, Rempel et al. 2007). In Ontario, forest harvest guidelines have recently been updated (OMNR 2010), but further evaluation is needed to determine how well they meeting the coarse-filter needs of wildlife. Harvest management of Canada's boreal region needs to incorporate long-term and landscape-scale monitoring of both forest habitats and wildlife in ways that recognize spatial and temporal variability in abundance and the dynamic nature of these ecosystems (Thompson and Harestad 2004, Venier et al. 2014).

\section{Responses to this article can be read online at: http://www.ace-eco.org/issues/responses.php/1102}

\section{Acknowledgments:}

This project was carried out under the auspices of Bird Studies Canada. We would like to thank our many project partners who provided assistance of various sorts to make this research possible. Our industry partners: Abitibi-Consolidated Company of Canada Limited, Algonquin Forestry Authority, Bowater Canada Incorporated, Domtar Incorporated, Kimberly-Clark Incorporated, Tembec Incorporated, and Weyerhaeuser Company of Canada provided maps and treatment history data for this report. Our other partners: Ontario Ministry of Natural Resources, Ontario Parks, Canadian Wildlife Service, Canadian Forest Service, Ontario Breeding Bird Atlas, University of Guelph, and LGL Limited all provided logistical expertise and assisted with project design and field sampling. Tom Nudds, Rob Rempel, Mike Cadman, and Michael Bradstreet provided invaluable insight and advice during project design, fieldwork, and preparation of this manuscript. Bird Studies Canada's National Scientific Advisory Committee and many colleagues, especially Fiona Schmiegelow, as well as two anonymous reviewers, provided helpful comments on earlier versions of this manuscript. Doug Tozer, Research Assistant with the project, provided invaluable assistance with many aspects of this research. Andrew Couturier provided GIS support, including preparing the map of study locations. This research would not have been possible if it were not for the 24 highly-skilled biologists conducting fieldwork in some of the most rugged terrain in Ontario. Finally, we would like to acknowledge the George Cedric Metcalf Charitable Foundation and the Ontario Living Legacy Trust for their financial support of this research. 


\section{LITERATURE CITED}

Askins, R. A. 2000. Restoring North America's birds: lessons from landscape ecology. Yale University Press, New Haven, Connecticut, USA.

Attiwill, P. M. 1994. The disturbance of forest ecosystems: the ecological basis for conservation management. Forest Ecology and Management 63:247-300. http://dx.doi.org/10.1016/0378-1127 (94)90114-7

Bélisle, M., A. Desrochers, J.-F. Gobeil, and M. Villard. 2007. Are boreal Ovenbirds, Seiurus aurocapilla, more prone to move across inhospitable landscapes in Alberta's boreal mixedwood forest than in southern Québec's temperate deciduous forest? Avian Conservation and Ecology - Écologie et conservation des oiseaux 2 (2):1. http://dx.doi.org/10.5751/ACE-00153-020201

Bergeron, Y., A. Leduc, B. D. Harvey, and S. Gauthier. 2002. Natural fire regime: a guide for sustainable management of the Canadian boreal forest. Silva Fennica 36:81-95. http://dx.doi. org/10.14214/sf.553

Blancher, P. 2003. Importance of Canada's boreal forest to landbirds. Canadian Boreal Initiative, Ottawa, Ontario, Canada, and Boreal Songbird Initiative, Seattle, Washington, USA.

Blancher, P., and J. Wells. 2005. The boreal forest region: North America's bird nursery. Canadian Boreal Initiative, Ottawa, Ontario, Canada, and Boreal Songbird Initiative, Seattle, Washington, USA.

Blancher, P. J., R. D. Phoenix, D. S. Badzinski, M. D. Cadman, T. L. Crewe, C. M. Downes, D. Fillman, C. M. Francis, J. Hughes, D. J. Hussell, D. Lepage, J. D. McCracken, D. K. McNicol, B. A. Pond, R. K. Ross, R. Russell, L. A. Venier, and R. C. Weeber. 2009. Population trend status of Ontario's forest birds. Forestry Chronicle 85:184-201. http://dx.doi.org/10.5558/tfc85184-2

Börger, L., and T. D. Nudds. 2014. Fire, humans, and climate: modeling distribution dynamics of boreal forest waterbirds. Ecological Applications 24:121-141. http://dx.doi.org/10.1890/12-1683.1

Brandt, J. P., M. D. Flannigan, D. G. Maynard, I. D. Thompson, and W. J. A. Volney. 2013. An introduction to Canada's boreal zone: ecosystem processes, health, sustainability, and environmental issues. Environmental Reviews 21:207-226. http:// dx.doi.org/10.1139/er-2013-0040

Bunnell, F. L. 1995. Forest-dwelling vertebrate faunas and natural fire regimes in British Columbia: patterns and implications for conservation. Conservation Biology 9:636-664. http://dx.doi. org/10.1046/j.1523-1739.1995.09030636.x

Cadman, M. D., D. A. Sutherland, G. G. Beck, D. Lepage, and A. R. Couturier. 2007. Atlas of the breeding birds of Ontario, 2001-2005. Bird Studies Canada, Environment Canada, Ontario Field Ornithologists, Ontario Ministry of Natural Resources, and Ontario Nature, Toronto, Ontario, Canada.

Campbell, B. D. 2001. The influence of forest harvesting and fire on breeding birds of mature boreal mixedwood forests in Northeastern Ontario. Thesis. University of Toronto, Toronto, Ontario, Canada.

Cardinale, B. J., J. E. Duffy, A. Gonzalez, D. U. Hooper, C. Perrings, P. Venail, A. Narwani, G. M. Mace, D. Tilman, D. A.
Wardle, A. P. Kinzig, G. C. Daily, M. Loreau, J. B. Grace, A. Larigauderie, D. S. Srivastava, and S. Naeem. 2012. Biodiversity loss and its impacts on humanity. Nature 486:59-67. http://dx.doi. org/10.1038/nature11148

Carpenter, B., A. Gelman, M. D. Hoffman, D. Lee, B. Goodrich, M. Betancourt, M. Brubaker, J. Guo, P. Li, and A. Riddell. 2017. Stan: a probabilistic programming language. Journal of Statistical Software 76(1). http://dx.doi.org/10.18637/jss.v076.i01

Cumming, E. E., and A.W. Diamond. 2002. Songbird community composition vs. forest rotation age in Saskatchewan boreal mixedwood forest. Canadian Field-Naturalist 116:69-75.

Cyr, D., S. Gauthier, Y. Bergeron, and C. Carcaillet. 2009. Forest management is driving the eastern North American boreal forest outside its natural range of variability. Frontiers in Ecology and Environment 7:519-524. http://dx.doi.org/10.1890/080088

Delong, S. C., and D. Tanner. 1996. Managing the pattern of forest harvest: lessons from wildfire. Biodiversity and Conservation 5:1191-1205. http://dx.doi.org/10.1007/BF00051571

Drapeau, P., A. Leduc, J.-F. Giroux, J.-P. L. Savard, Y. Bergeron, and W. L. Vickery. 2000. Landscape-scale disturbances and changes in bird communities of boreal mixed-wood forests. Ecological Monographs 70:423-444. http://dx.doi.org/10.1890/0012-9615 (2000)070[0423:LSDACI]2.0.CO;2

Drever, C. R., G. Peterson, C. Messier, Y. Bergeron, and M. Flannigan. 2006. Can forest management based on natural disturbances maintain ecological resilience? Canadian Journal of Forest Research 36:2285-2299. http://dx.doi.org/10.1139/x06-132

Farnsworth, G. L., J. D. McNicol, J. R. Sauer, S. G. Fancy, K. H. Pollock, S. A. Shriner, and T. R. Simons. 2005. Statistical approaches to the analysis of point count data: a little extra information can go a long way. General Technical Report PSWGTR-191. U.S. Forest Service, Pacific Southwest Research Station, Albany, California, USA.

Finch, D. M., J. L. Ganey, W. Yong, R. T. Kimball, and R. Sallabanks. 1997. Effects and interactions of fire, logging, and grazing. Pages 103-136 in W. M. Block, and D. M. Finch, editors. Songbird ecology in southwestern ponderosa pine forests: A literature review. General Technical Report RM-GTR-292. U.S. Forest Service, Rocky Mountain Forest and Range Experiment Station, Fort Collins, Colorado, USA.

Gelman, A., J. B. Carlin, H. S. Stern, D. B. Dunson, A. Vehtari, and D. B. Rubin. 2014. Bayesian data analysis. Third edition. Chapman and Hall/CRC, Boca Raton Florisa, USA.

Gower, S. T., R. E. McMurtrie, and D. Murty. 1996. Aboveground net primary production decline with stand age: potential causes. Trends in Ecology and Evolution 11:378-382. http://dx.doi. org/10.1016/0169-5347(96)10042-2

Haila, Y., I. K. Hanski, J. Niemelä, P. Punttila, S. Raivio, and H. Tukia. 1994. Forestry and the boreal forest: matching management with natural forest dynamics. Annales Zoologici Fennici 31:187-202.

Hannon, S. J. 1999. Avian response to stand and landscape structure in burned and logged landscapes in Alberta. Pages 24-29 in T. S. Veeman, D. W. Smith, B. G. Purdy, F. J. Salkie, and G. A. 
Larkin, editors. Science and practice: sustaining the boreal forest. The Sustainable Forest Management Network Conference, February 14-17, Edmonton, Alberta, Canada.

Hannon, S. J., and P. Drapeau. 2005. Bird responses to burns and clear cuts in the boreal forest of Canada. Pages 1104-1106 in C. J. Ralph, and T. D. Rich, editors. Bird Conservation Implementation and Integration in the Americas: Proceedings of the Third International Partners in Flight Conference. General Technical Report PSW-GTR-191. U.S. Forest Service, Pacific Southwest Research Station, Albany, California, USA.

Hobson, K. A., and E. Bayne. 2000. Breeding bird communities in boreal forest of western Canada: consequences of "unmixing" the mixedwoods. Condor 102:759-769

Hobson, K. A., and J. Schieck. 1999. Changes in bird communities in boreal mixedwood forest: harvest and wildfire effects over 30 years. Ecological Applications 9:849-863. http://dx.doi. org/10.1890/1051-0761(1999)009[0849:CIBCIB]2.0.CO;2

Hunter. M. L. 1993. Natural fire regimes as spatial models for managing boreal forests. Biological Conservation 65:115-120. http://dx.doi.org/10.1016/0006-3207(93)90440-C

Hutto, R. L. 1995. Composition of bird communities following stand-replacement fires in Northern Rocky Mountain (U.S.A.) conifer forests. Conservation Biology 9:1041-1058. http://dx.doi. org/10.1046/j.1523-1739.1995.9051033.x-i1

Imbeau, L., J.-P. L. Savard, and R. Gagnon. 1999. Comparing bird assemblages in successional black spruce stands originating from fire and logging. Canadian Journal of Zoology 77:1850-1860. http://dx.doi.org/10.1139/z99-172

Juffe-Bignoli, D., N. D. Burgess, H. Bingham, E. M. S. Belle, M. G. de Lima, M. Deguignet, B. Bertzky, A. N. Milam, J. MartinezLopez, E. Lewis, A. Eassom, S. Wicander, J. Geldmann, A. van Soesbergen, A. P. Arnell, B. O'Connor, S. Park, Y. N. Shi, F. S. Danks, B. MacSharry, and N. Kingston. 2014. Protected planet report 2014. UN Environment World Conservation Monitoring Centre, Cambridge, UK.

Kéry, M. 2010. Introduction to WinBUGS for ecologists: Bayesian approach to regression, ANOVA, mixed models and related analyses. Elsevier, Burlington, Massachusetts, USA.

Klenk, N., G. Bull, and D. Cohen. 2008. What is the "END" (emulation of natural disturbance) in forest ecosystem management? An open question. Canadian Journal of Forest Research 38:2159-2168. http://dx.doi.org/10.1139/X08-054

Kruschke, J. 2014. Doing Bayesian data analysis: a tutorial with $R, J A G S$, and Stan. Second edition. Academic Press, London, UK.

Kuuluvainen, T., and R. Grenfell. 2012. Natural disturbance emulation in boreal forest ecosystem management - theories, strategies, and a comparison with conventional even-aged management. Canadian Journal of Forest Research 42:1185-1203. http://dx.doi.org/10.1139/x2012-064

Lemelin, L. V., L. Imbeau, M. Darveau, and D. Bordage 2007. Local, short-term effects of forest harvesting on breeding waterfowl and Common Loon in forest-dominated landscapes of
Quebec. Avian Conservation and Ecology - Écologie et conservation des oiseaux 2(2):10. http://dx.doi.org/10.5751/ACE-00191-020210

Lewis, T. L., J. A. Schmutz, C. L. Amundson, and M. S. Lindberg. 2016. Waterfowl populations are resilient to immediate and lagged impacts of wildfires in the boreal forest. Journal of Applied Ecology 53:1746-1754. http://dx.doi.org/10.1111/1365-2664.12705

Lindén, A., and S. Mäntyniemi. 2011. Using the negative binomial distribution to model overdispersion in ecological count data. Ecology 92:1414-1421. http://dx.doi.org/10.1890/10-1831.1

Long, J. N. 2009. Emulating natural disturbance regimes as a basis for forest management: a North American view. Forest Ecology and Management 257:1868-1873. http://dx.doi.org/10.1016/j. foreco.2008.12.019

Macdonald, E., C. J. Burgess, G. J. Scrimgeour, S. Boutin, S. Reedyk, and B. Kotak. 2004. Should riparian buffers be part of forest management based on emulation of natural disturbance? Forest Ecology and Management 187:185-196. http://dx.doi. org/10.1016/S0378-1127(03)00330-X

Mayfield, M. M., S. P. Bonser, J. W. Morgan, I. Aubin, S. McNamara, and P. A. Vesk. 2010. What does species richness tell us about functional trait diversity? Predictions and evidence for responses of species and functional trait diversity to land-use change. Global Ecology and Biogeography 19:423-431. http://dx. doi.org/10.1111/j.1466-8238.2010.00532.X

McRae, D. J., L. C. Duchesne, B. Freedman, T. J. Lynham, and S. Woodley. 2001. Comparisons between wildfire and forest harvesting and their implications in forest management. Environmental Review 9:223-260. http://dx.doi.org/10.1139/ a01-010

Morissette, J. L., T. P. Cobb, R. M. Brigham, and P. C. James. 2002. The response of boreal forest songbird communities to fires and post-fire harvesting. Canadian Journal of Forest Research 32:2169-2183. http://dx.doi.org/10.1139/x02-134

Niemelä, J. 1999. Management in relation to disturbance in the boreal forest. Forest Ecology and Management 115:127-134. http://dx.doi.org/10.1016/S0378-1127(98)00393-4

Niemi, G., J. Hanowski,, P. Helle, R. Howe, M. Mönkkönen, L. Venier, and D. A. Welsh. 1998. Ecological sustainability of birds in boreal forests. Conservation. Ecology 2(2):17. http://dx.doi. org/10.5751/ES-00079-020217

North American Bird Conservation Initiative. 2016. The state of North America's Birds 2016. Environment and Climate Change Canada, Ottawa, Ontario, Canada. [online] URL: http://www. stateofthebirds.org/2016/

Ontario Ministry of Natural Resources (OMNR). 2001. Forest management guide for natural disturbance pattern emulation. Queen's Printer for Ontario, Toronto, Ontario, Canada. [online] URL: https://dr6j45jk9xcmk.cloudfront.net/documents/2801/guidenatural-disturbance.pdf

Ontario Ministry of Natural Resources (OMNR). 2010. Forest management guide for conserving biodiversity at the stand and site scales. Queen's Printer for Ontario, Toronto, Ontario, Canada. [online] URL: https://dr6j45jk9xcmk.cloudfront.net/documents/4816/ stand-amp-site-guide.pdf 
Paillet, Y., L. Bergès, L., J. Hjältén, P. Ódor, C. Avon, M. Bernhardt-Römermann, R-J. Bijlsma, L. De Bruyn, M. Fuhr, U. Grandin, R. Kanka, L. Lundin, S. Luque, T. Magura, S. Matesanz, I. Mészáros, M.-T. Sebastià, W. Schmidt, T. Standovár, B. Tóthmérész, A. Uotila, F. Valladares, K. Vellak, and R. Virtanen. 2010. Biodiversity differences between managed and unmanaged forests: meta-analysis on species richness in Europe. Conservation Biology 24:101-112. http://dx.doi.org/10.1111/ j.1523-1739.2009.01399.x

Perera, A., and L. J. Buse. 2004. Emulating natural disturbance in forest management. Pages 3-7 in A. Perera, L. J. Buse, and M. G. Weber, editors. Emulating natural forest landscape disturbances: concepts and applications. Columbia University Press, New York, New York, USA.

Perry, D. A. 1998. The scientific basis of forestry. Annual Review of Ecology and Systematics 29:435-466. http://dx.doi. org/10.1146/annurev.ecolsys.29.1.435

Rempel, R. S. 2007. Selecting focal songbird species for biodiversity conservation assessment: response to forest cover amount and configuration. Avian Conservation and Ecology Écologie et conservation des oiseaux 2(1):6. http://dx.doi. org/10.5751/ACE-00140-020106

Rempel, R. S., J. Baker, P. C. Elkie, M. J. Gluck, J. Jackson, R. S. Kushneriuk, T. Moore, and A. H. Perera. 2007. Forest policy scenario analysis: sensitivity of songbird community to changes in forest cover amount and configuration. Avian Conservation and Ecology - Écologie et conservation des oiseaux 2(1):5. http://dx. doi.org/10.5751/ACE-00139-020105

Rempel, R. S., B. J. Naylor, P. C. Elkie, J. Baker, J. Churcher, and M. J. Gluck. 2016. An indicator system to assess ecological integrity of managed forests. Ecological Indicators 60:860-869. http://dx.doi.org/10.1016/j.ecolind.2015.08.033

Schieck, J., and K. A. Hobson. 2000. Bird communities associated with live residual tree patches within cut blocks and burned habitat in mixedwood boreal forests. Canadian Journal of Forest Research 30:1281-1295. http://dx.doi.org/10.1139/x00-061

Schieck, J., M. Nietfeid, and J. B. Stelfox. 1995. Differences in bird species richness and abundance among three successional stages of aspen-dominated boreal forests. Canadian Journal of Zoology 73:1417-1431. http://dx.doi.org/10.1139/z95-167

Schieck, J., and S. J. Song. 2006. Changes in bird communities throughout succession following fire and harvest in boreal forests of western North America: literature review and meta-analyses. Canadian Journal of Forest Research 36:1299-1318. http://dx.doi. org/10.1139/x06-017

Schmiegelow, F. K. A., C. S. Machtans, and S. J. Hannon. 1997. Are boreal birds resilient to forest fragmentation? An experimental study of short-term community responses. Ecology 78:1914-1932. http://dx.doi.org/10.1890/0012-9658(1997)078[1914: ABBRTF]2.0.CO;2

Schmiegelow, F. K. A., and M. Monkkonen. 2002. Habitat loss and fragmentation in dynamic landscapes: avian perspectives from the boreal forest. Ecological Applications 12:375-389.
Schmiegelow, F. K. A., and M.-A. Villard. 2009. Conservation of boreal birds and the case for resilience: does it pass the test? Avian Conservation and Ecology - Écologie et conservation des oiseaux 4 (1):4. http://dx.doi.org/10.5751/ACE-00311-040104

Schulte, L. A., and G. J. Niemi. 1998. Bird communities of earlysuccessional burned and logged forest. Journal of Wildlife Management 62:1418-1429. http://dx.doi.org/10.2307/3802008

Secretariat of the Convention on Biological Diversity. 2014. Global biodiversity outlook 4. Secretariat of the Convention on Biological Diversity, Montréal, Québec, Canada.

Senate Subcommittee on the Boreal Forest. 1999. Competing realities: the boreal forest at risk. Senate of Canada, Ottawa, Ontario, Canada. [online] URL: http://www.parl.gc.ca/content/ sen/committee/361/bore/rep/rep09jun99-e.htm

Sibley, P. K., D. P. Kreutzweiser, B. J. Naylor, J. S. Richardson, and A. M. Gordon. 2012. Emulation of natural disturbance (END) for riparian forest management: synthesis and recommendations. Freshwater Science 31:258-264. http://dx.doi. org/10.1899/11-094.1

Simon, N. P. P., F. E. Schwab, and R. D. Otto. 2002. Songbird abundance in clear-cut and burned stands: a comparison of natural disturbance and forest management. Canadian Journal of Forest Research 32:1343-1350. http://dx.doi.org/10.1139/x02-057

Song, S. J. 2002. Ecological basis for standmanagement: a synthesis of ecological responses to wildfire and harvesting. Alberta Research Council Inc., Vegreville, Alberta, Canada.

Stan Development Team. 2016. RStan: the R interface to Stan. $R$ package version 2.14.1. http://mc-stan.org/

Thompson, I. D. 2000. Forest vegetation of Ontario: factors influencing landscape change. Pages 30-53 in A. H. Perera, D. L. Euler, and I. D. Thompson, editors. Ecology of a managed terrestrial landscape: patterns and processes of forest landscapes in Ontario. UBC Press, Vancouver, British Columbia, Canada.

Thompson, I. D., and A. S. Harestad. 2004. The ecological and genetic basis for emulating natural disturbance in forest management. Pages 29-42 in A. Perera, L. J. Buse, and M. G. Weber, editors. Emulating natural forest landscape disturbances: concepts and applications. Columbia University Press, New York, New York, USA.

Thompson, I. D., H. A. Hogan, and W. A. Montevechhi. 1999. Avian communities of mature balsam fir forests in Newfoundland: age-dependence and implications of timber harvesting. Condor 101:311-323. http://dx.doi.org/10.2307/1369994

Tiedemann, A. R., J. O. Klemmedson, and E. L. Bull. 2000. Solution of forest health problems with prescribed fire: Are forest productivity and wildlife at risk? Forest Ecology and Management 127:1-18. http://dx.doi.org/10.1016/S0378-1127(99)00114-0

Tilman, D., D. Wedlin, and J. Knops. 1996. Productivity and sustainability influenced by biodiversity in grassland ecosystems. Nature 379:718-720. http://dx.doi.org/10.1038/379718a0

Titterington, R. W., H. S. Crawford, and B. N. Burgason. 1979. Songbird responses to commercial clear-cutting in Maine spruce- 
fir forests. Journal of Wildlife Management 43:602-609. http://dx. doi.org/10.2307/3808737

Van Wilgenburg, S. L., and K. A. Hobson. 2008. Landscape-scale disturbance and boreal forest birds: Can large single-pass harvest approximate fires? Forest Ecology and Management 256:136-146. http://dx.doi.org/10.1016/j.foreco.2008.04.017

Venier, L. A., I. D. Thompson, R. Fleming, J. Malcolm, I. Aubin, J. A. Trofymow, D. Langor, R. Sturrock, C. Patry, R. O. Outerbridge, S. B. Holmes, S. Haeussler, I. De Grandpré, H. Y. H. Chen, E. Bayne, A. Arsenault, and J. P. Brandt. 2014. Effects of natural resource development on the terrestrial biodiversity of Canadian boreal forests. Environmental Reviews 22:457-490. http://dx.doi.org/10.1139/er-2013-0075

Vitz, A. C., and A. D. Rodewald. 2006. Can regenerating clearcuts benefit mature-forest songbirds? An examination of postbreeding ecology. Biological Conservation 127:477-486. http://dx. doi.org/10.1016/j.biocon.2005.09.011

Welsh, D. A. 1981. Birds as indicators of forest stand condition in boreal forests of eastern Canada. ICBP Technical Publication 6:259-267.

Welsh, D. A. 1987. The influence of forest harvesting on mixed coniferous-deciduous boreal bird communities in Ontario, Canada. Acta Ecologia 8:247-252.

Welsh, D. A., and L. A. Venier. 1996. Binoculars and satellites: developing a conservation framework for boreal forest wildlife at varying scales. Forest Ecology and Management 85:53-65. http:// dx.doi.org/10.1016/S0378-1127(96)03750-4

Whitaker, D. M., P. D. Taylor, and I. G. Warkentin. 2008. Survival of adult songbirds in boreal forest landscapes fragmented by clearcuts and natural openings. Avian Conservation and Ecology - Écologie et conservation des oiseaux 3(1):5. http://dx.doi. org/10.5751/ACE-00223-030105

Wyshynski, S. A., and T. D. Nudds. 2009. Pattern and process in forest bird communities on boreal landscapes originating from wildfire and timber harvest. Forestry Chronicle 85:218-226 http:// dx.doi.org/10.5558/tfc85218-2

Zhang, Y., H. Y. H. Chen, and P. B. Reich. 2012. Forest productivity increases with evenness, species richness and trait variation: a global meta-analysis. Journal of Ecology 100:742-749. http://dx.doi.org/10.1111/j.1365-2745.2011.01944.x

Zimmerling, J. R. 2005. Detectability of non-passerines using "pishing" in eastern Ontario woodlands. Canadian FieldNaturalist 119:377-380. http://dx.doi.org/10.22621/cfn.v119i3.148

Zimmerling, J. R., and C. D. Ankney. 2000. A technique that increases detectability of passerine species during point counts. Journal of Field Ornithology 71:638-649. http://dx.doi. org/10.1648/0273-8570-71.4.638

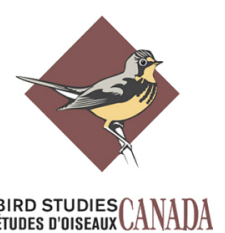


Appendix 1. English and scientific names of boreal bird species evaluated in this study, number of individuals $(n)$, and percent of all point counts on which the species was detected (\% point counts), ordered alphabetically by their 4-letter abbreviation codes.

\section{Code English name}

$\begin{array}{ll}\text { ALFL } & \text { Alder Flycatcher } \\ \text { AMCR } & \text { American Crow } \\ \text { AMRE } & \text { American Redstart } \\ \text { AMRO } & \text { American Robin } \\ \text { BAWW } & \text { Black-and-white Warbler } \\ \text { BBWA } & \text { Bay-breasted Warbler } \\ \text { BBWO } & \text { Black-backed Woodpecker } \\ \text { BCCH } & \text { Black-capped Chickadee } \\ \text { BHVI } & \text { Blue-headed Vireo } \\ \text { BLBW } & \text { Blackburnian Warbler } \\ \text { BLJA } & \text { Blue Jay } \\ \text { BOCH } & \text { Boreal Chickadee } \\ \text { BRCR } & \text { Brown Creeper } \\ \text { BTBW } & \text { Black-throated Blue } \\ & \text { Warbler } \\ \text { BTNW } & \text { Black-throated Green } \\ \text { CAWA } & \text { Warbler } \\ \text { CEDW } & \text { Cedar Wada Warbler } \\ \text { CHSP } & \text { Chipping Sparrow } \\ \text { CMWA } & \text { Cape May Warbler } \\ \text { CONW } & \text { Connecticut Warbler } \\ \text { CORA } & \text { Common Raven } \\ \text { COYE } & \text { Common Yellowthroat } \\ \text { CSWA } & \text { Chestnut-sided Warbler } \\ \text { DEJU } & \text { Dark-eye Junco } \\ \text { DOWO } & \text { Downy Woodpecker } \\ \text { EVGR } & \text { Evening Grosbeak } \\ \text { GCKI } & \text { Golden-crowned Kinglet } \\ \text { GRAJ } & \text { Gray Jay } \\ \text { HAWO } & \text { Hairy Woodpecker } \\ \text { HETH } & \text { Hermit Thrush } \\ \text { LEFL } & \text { Least Flycatcher } \\ \text { LISP } & \text { Lincoln's Sparrow } \\ \text { MAWA } & \text { Magnolia Warbler } \\ \text { MOWA } & \text { Mourning Warbler } \\ \text { NAWA } & \text { Nashville Warbler } \\ \text { NOFL } & \text { Northern Flicker } \\ \text { NOPA } & \text { Northern Parula } \\ & \end{array}$

Scientific name

Empidonax alnorum

Corvus brachyrhynchos

Setophaga ruticilla

Turdus migratorius

Mniotilta varia

Setophaga castanea

Picoides arcticus

Poecile atricapillus

Vireo solitaries

Setophaga fusca

Cyanocitta cristata

Poecile hudsonicus

Certhia americana

Setophaga caerulescens

Setophaga virens

Cardellina canadensis

Bombycilla cedrorum

Spizella passerina

Setophaga tigrina

Oporornis agilis

Corvus corax

Geothlypis trichas

Setophaga pensylvanica

Junco hyemalis

Picoides pubescens

Coccothraustes

vespertinus

Regulus satrapa

Perisoreus canadensis

Picoides villosus

Catharus guttatus

Empidonax minimus

Melospiza lincolnii

Setophaga magnolia

Geothlypis philadelphia

Oreothlypis ruficapilla

Colaptes auratus

Setophaga americana

\section{n}

1229

207

1089

1040

824

538

96

1332

648

738

455

247

363

415

695

345

1194

1262

84

105

337

1030

1607

849

179

196

1399

634

293

2261

1073

873

3804

1335

5939

550

241

\section{$\%$ point} counts

12.7

2.5

12.1

12.1

10.7

6.7

1.2

12.3

7.8

9.1

5.1

2.8

4.7

5.0

7.6

4.3

10.2

13.7

1.1

1.3

3.3

11.1

17.7

9.9

2.2

1.7

15.6

6.4

3.7

23.3

9.6

8.7

40.6

14.4

53.2

6.9

3.1 


$\begin{array}{lllrl}\text { NOWA } & \text { Northern Waterthrush } & \text { Parkesia noveboracensis } & 229 & 2.8 \\ \text { OSFL } & \text { Olive-sided Flycatcher } & \text { Contopus cooperi } & 76 & 1.0 \\ \text { OVEN } & \text { Ovenbird } & \text { Seiurus aurocapilla } & 3303 & 33.6 \\ \text { PAWA } & \text { Palm Warbler } & \text { Setophaga palmarum } & 414 & 4.5 \\ \text { PHVI } & \text { Philadelphia Vireo } & \text { Vireo philadelphicus } & 170 & 2.2 \\ \text { PISI } & \text { Pine Siskin } & \text { Spinus pinus } & 321 & 3.3 \\ \text { PIWO } & \text { Pileated Woodpecker } & \text { Dryocopus pileatus } & 159 & 2.1 \\ \text { PUFI } & \text { Purple Finch } & \text { Haemorhous purpureus } & 210 & 2.8 \\ \text { RBGR } & \text { Rose-breasted Grosbeak } & \text { Pheucticus ludovicianus } & 116 & 1.4 \\ \text { RBNU } & \text { Red-breasted Nuthatch } & \text { Sitta canadensis } & 957 & 11.6 \\ \text { RCKI } & \text { Ruby-crowned Kinglet } & \text { Regulus calendula } & 1196 & 14.2 \\ \text { REVI } & \text { Red-eyed Vireo } & \text { Vireo olivaceus } & 4760 & 43.7 \\ \text { RUGR } & \text { Ruffed Grouse } & \text { Bonasa umbellus } & 217 & 3.0 \\ \text { SOSP } & \text { Song Sparrow } & \text { Melospiza melodia } & 558 & 5.9 \\ \text { SWSP } & \text { Swamp Sparrow } & \text { Melospiza georgiana } & 498 & 5.6 \\ \text { SWTH } & \text { Swainson's Thrush } & \text { Catharus ustulatus } & 2669 & 27.7 \\ \text { TEWA } & \text { Tennessee Warbler } & \text { Oreothlypis peregrina } & 391 & 4.7 \\ \text { VEER } & \text { Veery } & \text { Catharus fuscescens } & 826 & 8.9 \\ \text { WIWA } & \text { Wilson's Warbler } & \text { Cardellina pusilla } & 144 & 1.7 \\ \text { WIWR } & \text { Winter Wren } & \text { Troglodytes hiemalis } & 1890 & 23.2 \\ \text { WTSP } & \text { White-throated Sparrow } & \text { Zonotrichia albicollis } & 7088 & 54.5 \\ \text { WWCR } & \text { White-winged Crossbill } & \text { Loxia leucoptera } & 958 & 6.2 \\ \text { YBFL } & \text { Yellow-bellied Flycatcher } & \text { Empidonax flaviventris } & 1584 & 18.6 \\ \text { YBSA } & \text { Yellow-bellied Sapsucker } & \text { Sphyrapicus varius } & 460 & 5.8 \\ \text { YRWA } & \text { Yellow-rumped Warbler } & \text { Setophaga coronata } & 2785 & 31.3\end{array}$


Appendix 2. Predicted mean number of boreal birds detected per point count per species in each of five habitat types in northern Ontario forest stands, after adjusting for differences among Bird Conservation Regions and treating transects as a random effect (see Methods for model details). Values are plotted by age class (ER: early-regenerating, MR: midregenerating, M: mature) and by disturbance type (black $=$ postfire, grey $=$ postharvest). Dots represent the mean and bars represent the 95\% Bayesian credible intervals. See Appendix 1 for full English and scientific names corresponding to each species' 4-letter code.

ALFL

AMCR

AMRE
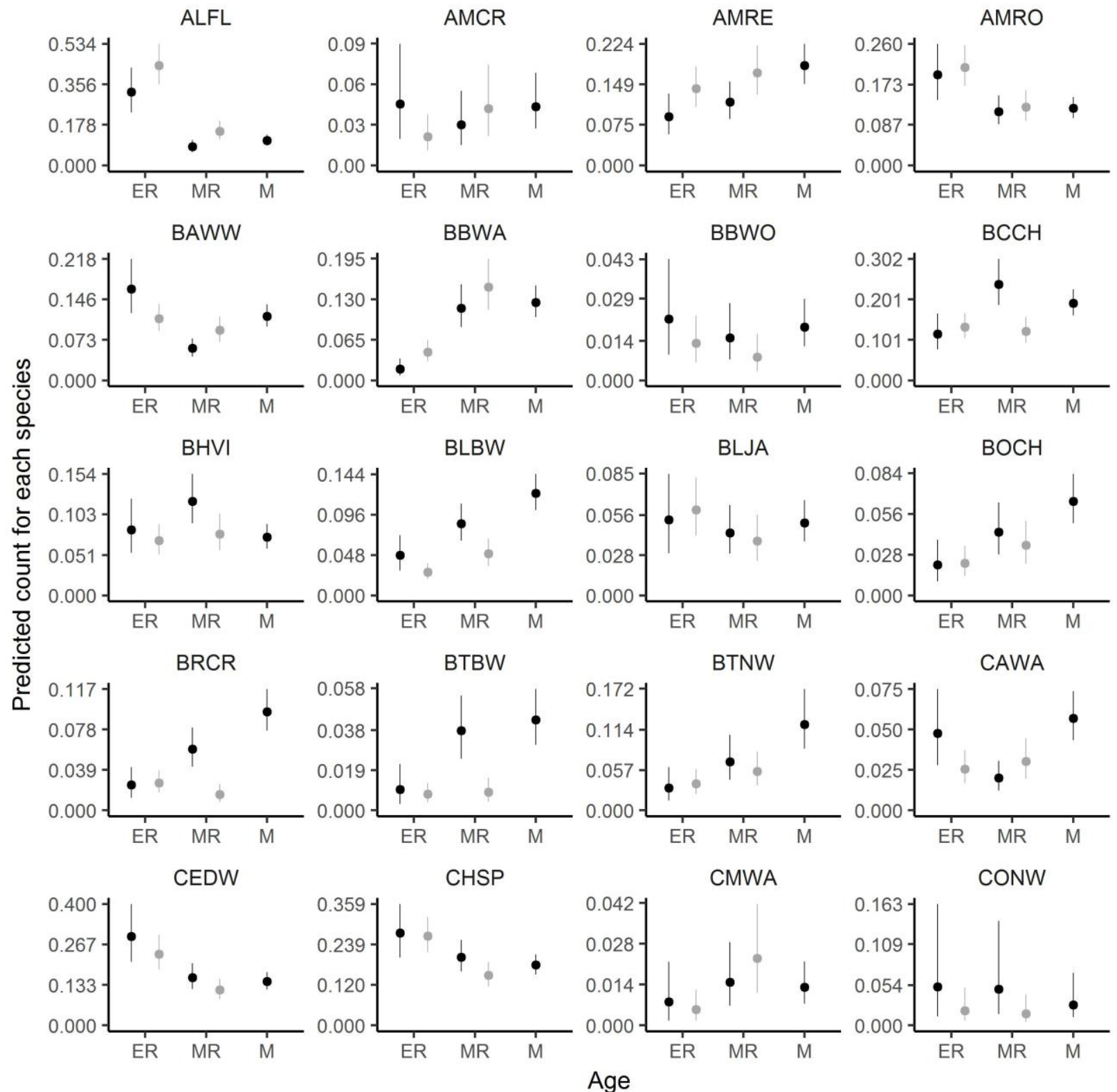


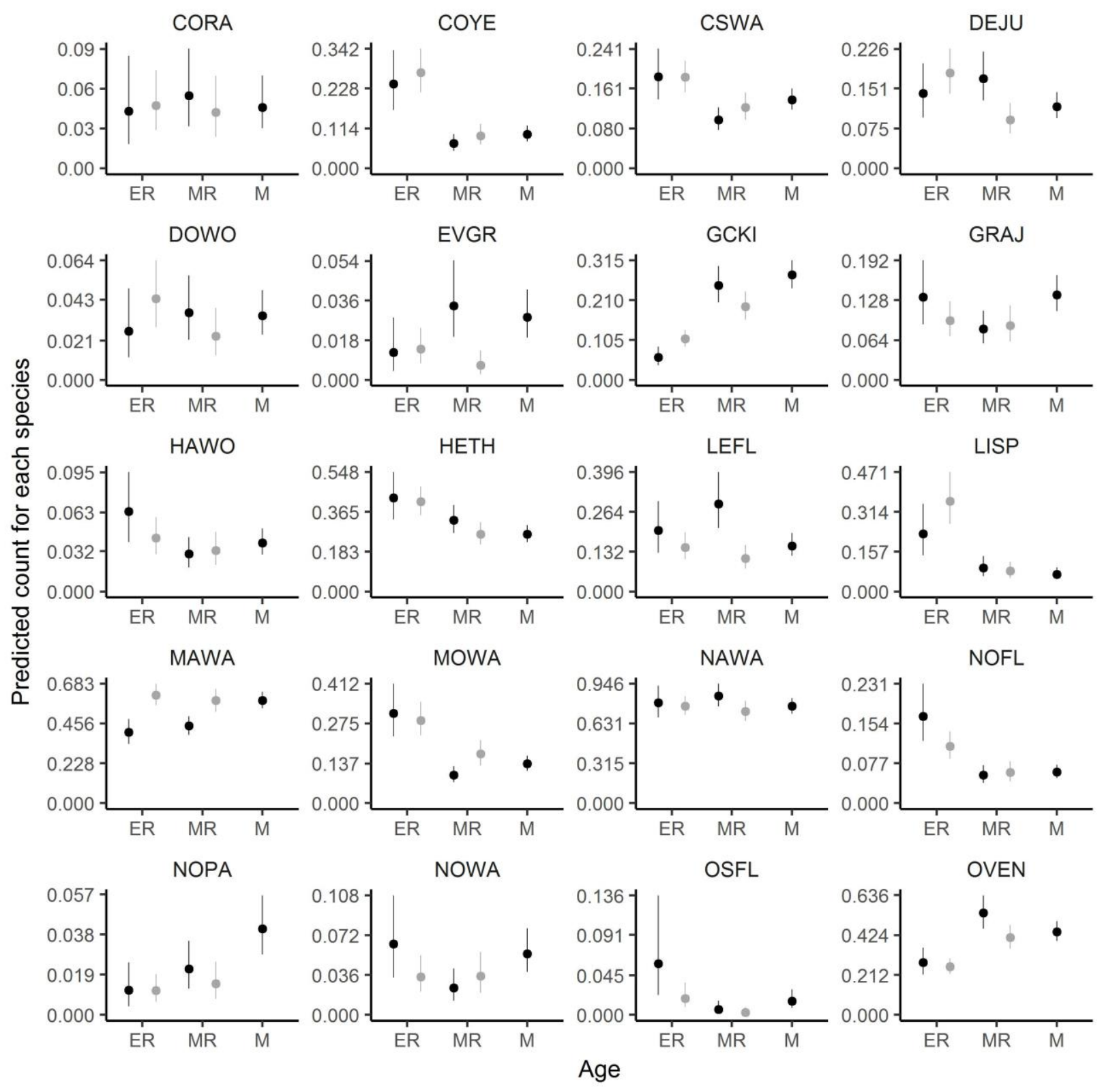




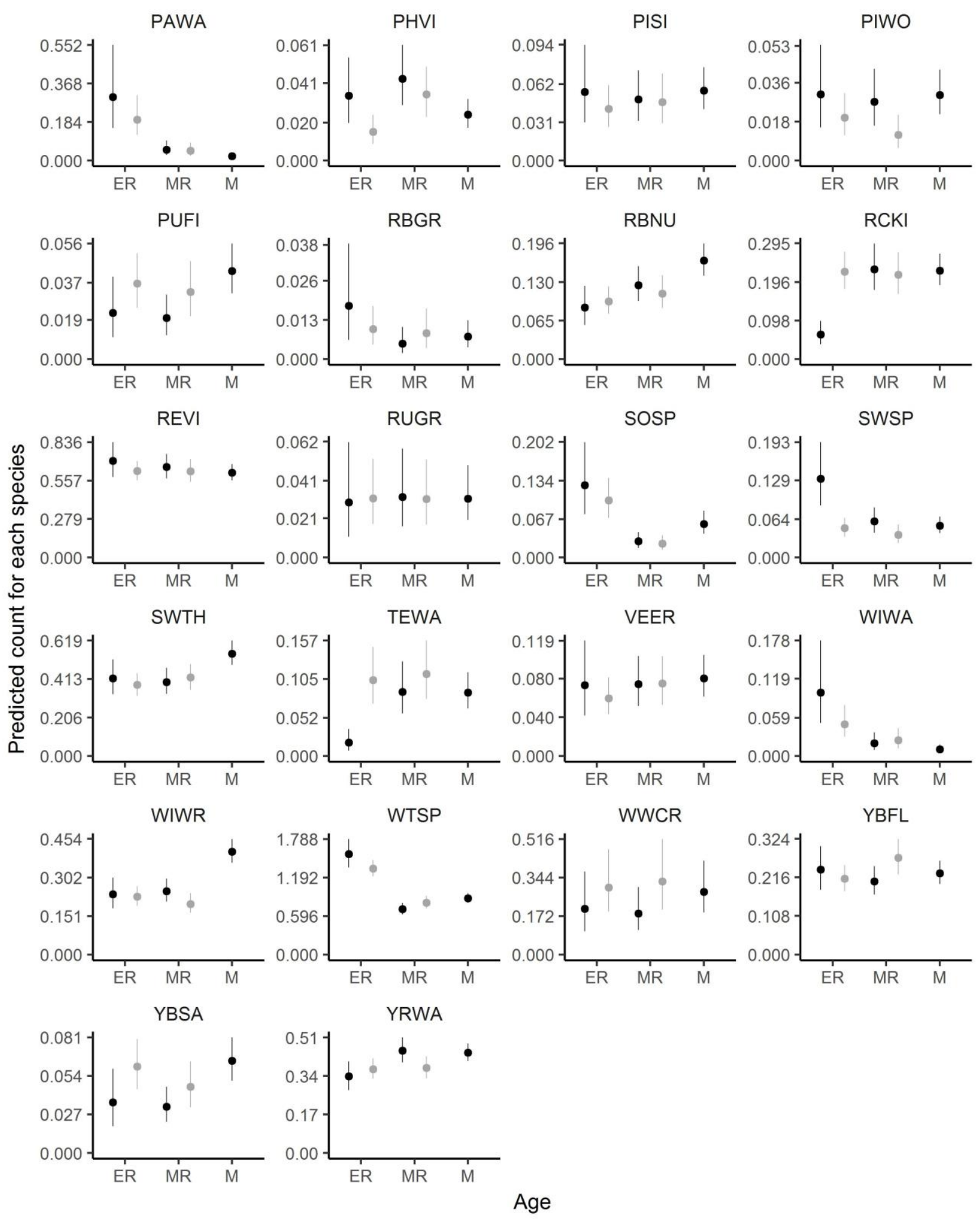


Appendix 3. Comparisons of contrasts for individual species between (a) early-regenerating postfire vs. mature forest compared with midregenerating postfire vs. mature forest; (b) harvest vs. fire in early-regenerating compared to harvest vs. fire in midregenerating forests; (c) harvest vs. fire in early-regenerating forests compared to early-regenerating postfire vs. mature forest; and (d) harvest vs. fire in midregenerating stands compared to midregenerating post-fire vs. mature forest. Dots represent the estimated contrast on the natural logarithmic scale (where a value of 0.7 corresponds to double (or half) the abundance). For example, species in the upper half of (a) occurred more frequently in midregenerating postfire forest than mature forest, and species on the right side of (a) were also more abundant in early-regenerating postfire forest than mature forest. Black labels indicate species for which both contrasts were significant ( $95 \%$ credible intervals do not overlap zero); blue labels indicate species for which the contrast on the $\mathrm{x}$-axis was significant but not the contrast on the $\mathrm{y}$ axis; green labels indicate species for which the contrast on the $y$-axis was significant but not the contrast on the $\mathrm{x}$-axis; and grey labels identify species for which neither contrast was significant.
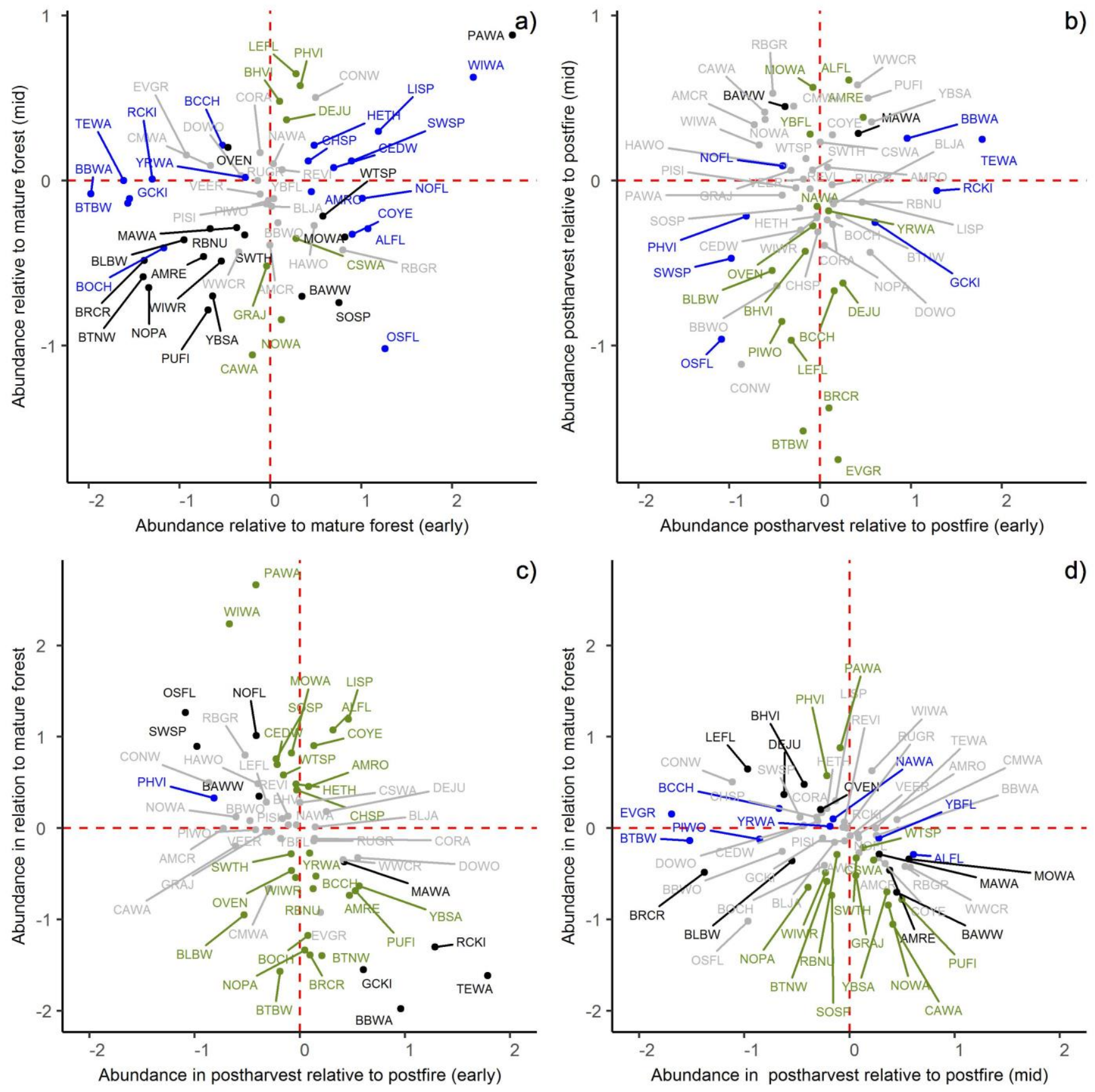